\begin{abstract}
MICHAŁ PONIATOWSKI
Wydział Prawa Kanonicznego

Uniwersytet Kardynała Stefana Wyszyńskiego w Warszawie

ORCID: 0000-0002-7263-4550
\end{abstract}

\title{
KOŚCIELNE OSOBY PRAWNE JAKO \\ ORGANIZACJE POZARZĄDOWE UCZESTNICZACCE W UMOWNYM WSPÓŁDZIAŁANIU W RAMACH USTAWY O PRZECIWDZIAŁANIU MARNOWANIA ŻYWNOŚCI
}

Treść: Wstęp. - 1. Forma umowy współdziałania. - 2. Podmioty współdziałania. - 3. Przedmiot współdziałania. - Zakończenie.

\section{Wstęp}

Szacunek do żywności niewątpliwie stanowi nie tylko element polskiej tradycji, ale ma swoje źródła w naturze człowieka. Taki stosunek do żywności przejawia się w licznych płaszczyznach, w tym religijnej, etycznej czy też prawnej. Obowiązek przeciwdziałania marnowania żywności może być zatem oceniany w różnych kategoriach, w tym grzechu, czy też dobra i zła lub przestrzegania prawa.

W Piśmie Świętym odnaleźć można wiele przykładów wskazujących na obowiązek szanowania żywności, rozumianej jako wszystko co nadaje się do jedzenia, stanowiąc dla ludzi pokarm, zaś dla zwierząt paszę 1 . W Starym Testamencie żywność jest częstokroć darem od

\footnotetext{
${ }^{1}$ Por. $\operatorname{Rdz} 6,21$.
} 
Boga $^{2}$. Ponadto chęć jedzenia ma charakter naturalny ${ }^{3}$. W Nowym Testamencie również można zauważyć szacunek do żywności. Jezus Chrystus po cudownym rozmnożeniu chleba zwrócił się do uczniów: „Zbierzcie pozostałe ułomki, aby nic nie zginęło”, którzy je zebrali i napełnili dwanaście koszów ${ }^{4}$. Przedmiotowy szacunek można odnaleźć również w Modlitwie Pańskiej ${ }^{5}$. Wymóg szanowania żywności jest jeszcze bardziej aktualny w dzisiejszych czasach. Papież Franciszek w encyklice Laudato Si z dnia 24 maja 2015 r. krytycznie odniósł się do faktu, że blisko jedna trzecia produkowanej żywności jest marnotrawiona ${ }^{6}$.

W polskim społeczeństwie marnotrawienie żywności jest niewątpliwie oceniane negatywnie, w szczególności w kontekście dotychczasowych doświadczeń historycznych w XIX i XX w.

W polskim porządku prawnym niestety dopiero poprzez wejście w życie ustawy z dnia 19 lipca 2019 r. o przeciwdziałaniu marnowania żywności ${ }^{7}$ dokonano stopniowego uregulowania kwestii związanych $\mathrm{z}$ przedmiotowym przeciwdziałaniem marnowania żywności ${ }^{8}$.

${ }^{2}$ Por. Wj 16, 8; Lb 11, 18.

${ }^{3}$ Por. Mdr 16, 3.

${ }^{4}$ J 6, 12. Por. także Mt 14, 20; Mt 15, 37; Mk 6, 43; Mk 8, 8; Łk 9, 17. Co istotne zebranie ułomków miało miejsce zarówno przy pierwszym jak i drugim rozmnożeniu chleba co wskazuje na stały obowiązek.

${ }^{5}$ Por. Mt 6, 11.

${ }^{6}$ FrANCISCI litterae encyclicae Laudato Si n. 50, AAS 107 (2015), 847-945.

${ }^{7}$ Dz. U. 2019 poz. 1680. Ustawa zwana dalej także u.p.ż.

${ }^{8}$ Jak wskazano w uzasadnieniu projektu ustawy: „W chwili obecnej w Polsce brak jest regulacji $w$ zakresie przeciwdziałania marnowaniu żywności. Jedynym udogodnieniem w tym zakresie sa korzystne przepisy podatkowe. Od dnia 1 stycznia 2009 r. zwolniono od podatku od towarów i usług darowiznę dokonywana przez producentów, której przedmiotem sa produkty spożywcze, z wyjątkiem napojów alkoholowych o zawartości alkoholu powyżej 1,2\% oraz napojów alkoholowych będących mieszanina piwa i napojów bezalkoholowych, w których zawartość alkoholu przekracza 0,5\%, jeżeli sa one przekazywane na rzecz organizacji pożytku publicznego w rozumieniu ustawy z dnia 24 kwietnia 2003 r. o działalności pożytku publicznego i o wolontariacie, z przeznaczeniem na cele działalności charytatywnej prowadzonej przez te organizację. Natomiast z dniem 1 października 2013 r. zwolnienie dla darowizn wskazanej powyżej żywności dla organizacji pożytku publicznego zostało rozszerzone 
Ustawa ta stanowi obecnie novum, w szczególności w kontekście dotychczasowego braku szerszej działalności orzeczniczej co jest dosyć naturalne z uwagi na stosunkowo niedawne wejście w życie ustawy.

$\mathrm{W}$ ustawie tej istotnym elementem jest współdziałanie $\mathrm{z}$ organizacjami pozarządowymi w zakresie tego przeciwdziałania. Takimi organizacjami mogą być kościelne osoby prawne. $\mathrm{Z}$ uwagi na ramy niniejszego opracowania przedmiotowe zagadnienie zostanie przedstawione na przykładzie osób prawnych Kościoła katolickiego, nazywanymi na użytek niniejszego opracowania również kościelnymi osobami prawnymi.

\section{Forma umowy współdziałania}

W ramach przedmiotowej ustawy współdziałanie sprzedawców żywności i organizacji pozarządowych wymaga zawarcia umowy w formie pisemnej lub elektronicznej pod rygorem nieważności. Wymóg ten jest uregulowany w art. 3 ust. 1 ustawy o przeciwdziałaniu marnowania żywności, zgodnie z którym: „Sprzedawca żywności jest obowiązany do zawarcia umowy $w$ formie pisemnej lub elektronicznej pod rygorem nieważności z organizacja pozarządowa dotyczącej nieodpłatnego przekazywania żywności spełniajacej wymogi prawa żywnościowego, $w$ tym określone w rozporzadzeniu (WE) nr 178/2002, a nieprzeznaczonej do sprzedaży, w szczególności ze względu na wady wyglądu tej żywności albo jej opakowań, z wyjątkiem napojów alkoholowych o zawartości alkoholu powyżej 1,2\% oraz napojów alkoholowych będacych mieszanina piwa i napojów bezalkoholowych, $w$ których zawartość alkoholu przekracza 0,5\%, z przeznaczeniem na wykonywanie przez tę organizację zadań w zakresie określonym $w$ art. 2 pkt 2". Tym samym zawarcie umowy w innej formie np. ustnej skutkuje nieważnością umowy. Bez znaczenia dla ważności umowy będą miały w takim przypadku m.in. intencje stron czy też charytatywny charakter prowadzonej działalności przez organizację

o jej dystrybutorów i obecnie obejmuje wszystkich podatników dokonujących takich darowizn. Wskazane udogodnienia nie stanowia jednak wystarczajacej regulacji w tym zakresie”. Druk sejmowy nr 2431 z dnia 19 marca 2018 r., s. 3. 
pozarządową. Forma umowy przewidziana w ustawie tym samym determinuje sposób współdziałania tych podmiotów.

Ponadto dla zachowania właściwej formy wymagana jest uprzednia właściwa reprezentacja stron. Dodatkowo w przypadku kościelnych osób prawnych - wobec mogących się pojawić istotnych zagrożeń dla ich sytuacji majątkowej poprzez różnego rodzaju zabezpieczenia konieczne może się okazać uzyskanie odpowiednich zgód, w tym Konferencji Episkopatu Polski lub nawet Stolicy Apostolskiej z uwagi na wymogi dotyczące alienacji przewidziane w prawie kanonicznym.

Treść art. art. 3 ust. 1 ustawy o przeciwdziałaniu marnowania żywności expressis verbis nakłada obowiązek zawarcia umowy jedynie na sprzedawcę żywności. Obowiązek ten jest połączony z sankcją ${ }^{9}$. Tym samym taki obowiązek wynikający z samej ustawy nie spoczywa na kościelnych osobach prawnych. Pomimo braku takiego obowiązku kościelne osoby prawne mając na uwadze obowiązki wynikające $\mathrm{z}$ ich działalności statutowej powinny być otwarte do zawierania przedmiotowych umów, oczywiście o ile ich treść nie jest niekorzystna dla tychże kościelnych osób prawnych.

\section{Podmioty współdziałania}

Umowa dotycząca przeciwdziałania marnowania żywności jak już wskazano jest zawierana między sprzedawcą żywności i organizacją pozarządową. Ustawa zawiera definicje legalne stron umowy.

Zgodnie z art. 2 pkt 3) ustawy sprzedawca żywności to „[...] podmiot prowadzacy przedsiębiorstwo spożywcze, o którym mowa w art. 3 ust. 3 rozporządzenia (WE) nr 178/2002, w zakresie sprzedaży $\dot{z} y w$ ności $w$ jednostce handlu detalicznego lub hurtowego o powierzchni sprzedaży w rozumieniu art. 2 pkt 19 ustawy z dnia 27 marca 2003 r. o planowaniu i zagospodarowaniu przestrzennym (Dz.U. z 2018 r. poz.

\footnotetext{
${ }^{9}$ Warto wskazać, że zgodnie z treścią art. 10 u.p.m.ż., który wejdzie w życie w dniu 1 marca 2020 r.: „Kto wbrew obowiązkowi określonemu w art. 3 ust. 1, nie zawiera z organizacja pozarzadowa umowy dotyczacej nieodpłatnego przekazywania żywności, z przeznaczeniem na wykonywanie przez tę organizację zadań w zakresie określonym $w$ art. 2 pkt 2, podlega karze pieniężnej w wysokości 5000 zł”.
} 


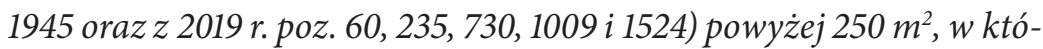
rej przychody ze sprzedaży żywności stanowia co najmniej 50\% przychodów ze sprzedaży wszystkich towarów". Warto dodać, że definicja ta ma charakter docelowy w związku z przepisami przejściowymi. Na podstawie art. 17 ustawy: „W okresie 2 lat od dnia wejścia $w \dot{z} y c i e$ ustawy przez sprzedawcę żywności rozumie się podmiot prowadzacy

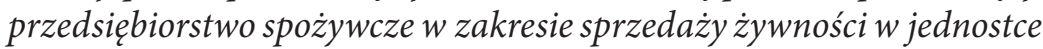
handlu detalicznego lub hurtowego o powierzchni sprzedaży w rozumieniu art. 2 pkt 19 ustawy $z$ dnia 27 marca 2003 r. o planowaniu i zagospodarowaniu przestrzennym powyżej $400 \mathrm{~m}^{2}$, w której przychody ze sprzedaży środków spożywczych stanowia co najmniej 50\% przychodów ze sprzedaży wszystkich towarów". Tym samym obecnie obowiązuje kryterium powierzchni sprzedaży żywności powyżej $400 \mathrm{~m}^{2}$. Organizacja pozarządowa przed podpisaniem umowy powinna z należytej ostrożności zapoznać się z odpowiednimi rejestrami, w tym Krajowym Rejestrem Sądowym czy też Centralną Ewidencją i Informacją o Działalności Gospodarczej, m.in. w kontekście sprawdzenia reprezentacji konkretnego sprzedawcy żywności czy też przedmiotu działalności gospodarczej, tym bardziej, iż te rejestry mają charakter jawny i nie można zasłaniać się ich nieznajomością.

Ustawodawca zawarł również specyficzną definicję legalną organizacji pozarządowej. Zgodnie z art. 2 pkt 2 ustawy o przeciwdziałaniu marnowania żywności organizacja pozarządowa oznacza: „[...] organizacje pozarzadowa oraz podmiot, o których mowa odpowiednio $w$ art. 3 ust. 2 i ust. 3 pkt 1 ustawy $z$ dnia 24 kwietnia 2003 r. o działalności pożytku publicznego i o wolontariacie (Dz.U. z 2019 r. poz. 688 $i$ 1570), których celem statutowym jest wykonywanie zadań w sferze zadań publicznych w zakresie: a) pomocy społecznej, w tym pomocy rodzinom i osobom $w$ trudnej sytuacji życiowej oraz wyrównywania szans tych rodzin i osób, b) wspierania rodziny i systemu pieczy zastępczej, c) działalności charytatywnej, polegającej w szczególności na przekazywaniu żywności osobom potrzebującym lub prowadzeniu zakładów żywienia zbiorowego dla osób potrzebujacych". Co ciekawe powyższa definicja organizacji pozarządowej ma charakter szeroki, albowiem mieści ona w sobie zarówno organizacje pozarządowe, 
o których mowa w art. 3 ust. 2 ustawy z dnia 24 kwietnia 2003 r. o działalności pożytku publicznego ${ }^{10}$, jak również osoby prawne i jednostki organizacyjne działające na podstawie przepisów o stosunku Państwa do Kościoła Katolickiego w Rzeczypospolitej Polskiej, o stosunku Państwa do innych kościołów i związków wyznaniowych oraz o gwarancjach wolności sumienia i wyznania, jeżeli ich cele statutowe obejmują prowadzenie działalności pożytku publicznego, o których mowa w art. 3 ust. 3 tej ustawy ${ }^{11}$. W tym drugim przypadku najczęściej będą to osoby prawne, o których mowa w art. 28 ust. 2 ustawy z dnia 17 maja 1989 r. o gwarancjach wolności sumienia i wyznania ${ }^{12}$ lub wymienione rodzajowo w tzw. indywidualnych ustawach wyznaniowych, w tym w art. 7-9 ustawy z dnia 17 maja 1989 r. o stosunku państwa do Kościoła Katolickiego w Rzeczypospolitej Polskiej ${ }^{13}$, a w szczególności Caritas diecezjalne oraz osoby prawne poszczególnych zgromadzeń zakonnych, których działalność często polega na pomaganiu ubogim poprzez wydawanie im produktów żywnościowych czy też gotowych posiłków.

W tym miejscu warto zauważyć, że w uzasadnieniu projektu ustawy w kontekście użytej definicji legalnej organizacji pozarządowej wskazano: „W odniesieniu do definicji «organizacji pozarzadowej» wprowadzono ponadto doprecyzowanie, iż walor wskazanej organizacji, rozumieniu projektu ustawy, posiadaja również osoby prawne i jednostki organizacyjne działajace na podstawie przepisów o stosunku Państwa do Kościoła Katolickiego, o stosunku Państwa do innych kościołów i związków wyznaniowych oraz o gwarancjach

${ }^{10}$ Tekst jedn. Dz. U. 2019 poz. 688 z póżn. zm. Ustawa zwana dalej także u.d.p.p.w.

${ }^{11} \mathrm{Na}$ kanwie samej ustawy o działalności pożytku publicznego i o wolontariacie, niektórzy autorzy są zdania, że kościelne osoby prawne nie są organizacjami pozarządowymi. Por. J. Kopyra, Ustawa o działalności pożytku publicznego i o wolontariacie. Komentarz, Warszawa 2005, s. 46.

${ }^{12}$ Tekst jedn. Dz. U. 2017 poz. 1153 z późn. zm. Ustawa zwana dalej także u.g.w.s.w.

${ }^{13}$ Tekst jedn. Dz. U. 2019 poz. 1347 z późn. zm. Ustawa zwana dalej także u.s.p.k.k. Por. także H. Misztal, Osobowość cywilnoprawna kościołów i innych związków wyznaniowych, w: A. Mezglewski, H. Misztal, P. Stanisz, Prawo wyznaniowe, Warszawa 2008, s. 129-135. 
wolności sumienia i wyznania, o których mowa w art. 3 ust. 3 pkt 1 ustawy z dnia 24 kwietnia 2003 r. o działalności pożytku publicznego i o wolontariacie. Przedmiotowe uregulowanie uwzględnia specyfike funkcjonowania kościelnych osób prawnych. Osoby te od wieków prowadza w Polsce działalność charytatywnoopiekuńcza, w tym rozdaja żywność ubogim a jednocześnie zachowuja swoja autonomię i specyfike działalności"14. W projekcie zauważono zatem dotychczasowe działania kościelnych osób prawnych w zakresie działalności charytatywno-opiekuńczej, której istotnym fundamentem jest rozdawanie żywności osobom ubogim ${ }^{15}$. Żeby taką żywność rozdawać, należy ją uprzednio odpowiednio uzyskać, najczęściej w drodze nieodpłatnej. Warto jednakże wspomnieć, iż początkowo zanim Senat przyjął ostateczny kształt projektu początkowo zawężano definicję organizacji pozarządowych wyłącznie do art. 3 ust. 2 ustawy o działalności pożytku publicznego. Proponowany zapis spotkał się jednak z krytyką wyrażoną przez kościelne osoby prawne, które poprzez taki zapis mogłyby zostać wyłączone z systemu przeciwdziałania marnowania żywności, w tym zawierania umów ze sprzedawcami żywności. Takie wyłączenie mogłoby wręcz doprowadzić do dyskryminacji kościelnych osób prawnych z powodów religijnych a nawet naruszać wolność religijną w aspekcie instytucjonalnym. Ostatecznie zatem przyjęto złożoną definicję organizacji pozarządowej co ma istotne znaczenie na kanwie pojawiających się w praktyce stanowisk jakoby to np. kościelne osoby prawne nie mogły się ubiegać o środki publiczne na poczet prowadzonej działalności charytatywnej z uwagi na to, że nie są organizacjami pozarządowymi. Podobnie szeroka definicja została zastosowana w aktualnym brzmieniu art. 2 pkt 3) ustawy z dnia 27 sierpnia 1997 r. o rehabilitacji zawodowej i społecznej oraz

\footnotetext{
${ }^{14}$ Por. druk sejmowy nr 2431, s. 4.

${ }^{15}$ Por. także S. PAwLik, Posługa charytatywna Kościoła w uchwałach polskich synodów po Soborze Watykańskim II. (Studium prawno-historyczne), Wrocław 2006, s. 134. Warto zauważyć, że w doktrynie w kontekście działalności pożytku publicznego kościelne osoby prawne są również nazywane wyznaniowymi osobami prawnymi. Por. P. STASzczyк, Ustawa o działalności pożytku publicznego i o wolontariacie. Komentarz, Warszawa 2013, s. 17.
} 
zatrudnianiu osób niepełnosprawnych ${ }^{16}$, zgodnie z którym organizacje pozarządowe oznaczają: „[...] organizacje pozarządowe oraz podmioty wymienione $w$ art. 3 ust. 3 ustawy z dnia 24 kwietnia 2003 r. o działalności pożytku publicznego i o wolontariacie (Dz.U. z 2019 r. poz. 688) [...]". Jednakże w kontekście równego traktowania organizacji pozarządowych należy wskazać, że sprzedawca żywności, który przekazuje żywność organizacji pozarządowej posiadającej status organizacji pożytku publicznego zyskuje możliwość odpowiedniego odliczenia podatku od towarów i usług, czego nie może już uczynić w przypadku przekazania żywności do organizacji pozarządowej bez takiego statusu. Oczywiście taki status mogą posiadać również kościelne osoby prawne, jednakże w ich przypadku jego nabycie nie ma - tak jak w przypadku innych organizacji pozarządowych - „naturalnego" charakteru i wymaga m.in. organizacyjnego wyodrębnienia tej działalności od pozostałej działalności, w tym tzw. kościelnej działalności miłosierdzia.

Ponadto w ustawowej definicji organizacji pozarządowej zawarto wymóg - skierowany zarówno do organizacji pozarządowych oraz podmiotów, o których mowa odpowiednio w art. 3 ust. 2 i ust. 3 pkt 1 u.d.p.p.w. - odpowiedniego celu statutowego polegającego na wykonywaniu co najmniej jednego zadania w sferze zadań publicznych tj. pomocy społecznej, w tym pomocy rodzinom i osobom w trudnej sytuacji życiowej oraz wyrównywania szans tych rodzin i osób, wspierania rodziny i systemu pieczy zastępczej lub działalności charytatywnej, polegającej w szczególności na przekazywaniu żywności osobom potrzebującym lub prowadzeniu zakładów żywienia zbiorowego dla osób potrzebujących. Wymóg ten nie oznacza zakazu prowadzenia innej działalności, w tym nawet działalności gospodarczej o ile jest ona odpowiednio wyodrębniona od nieodpłatnej lub odpłatnej działalności pożytku publicznego. Oczywiście kościelna osoba prawna może prowadzić również inne zadania mieszczące się w sferze zadań publicznych określonych w art. 4 u.d.p.p.w. lub w kościelnej działalności miłosierdzia.

${ }^{16}$ Tekst jedn. Dz. U. 2019 poz. 1172 z późn. zm. 


\section{Przedmiot współdziałania}

Przedmiot współdziałania jest określany w umowie zawieranej między sprzedawcą żywności i kościelną osobą prawną, która to umowa ma charakter cywilnoprawny, przy czym z uwagi, iż kościelne osoby prawne nie występują w tej relacji jako przedsiębiorcy nie ma ona charakteru umowy handlowej (gospodarczej) ${ }^{17}$. Tym samym umowa ta powinna zawierać standardowe elementy umowy cywilnoprawnej takie jak nazwa umowy, oznaczenie stron umowy (komparycja), przedmiot umowy, klauzule końcowe i w zależności od formy umowy odpowiednie oświadczenia stron o woli podpisania umowy (np. podpis w przypadku formy pisemnej).

Umowa ta stanowi istotny ale nie wyczerpujący element systemu przeciwdziałania marnowania żywności. Samo pojęcie marnowanie żywności zostało wyjaśnione w definicji legalnej zawartej w art. 2 pkt 1) u.p.m.ż. i oznacza ono: „[...] wycofywanie z etapu dystrybucji żywności, która spetnia wymogi prawa żywnościowego, w tym określone w rozporządzeniu (WE) nr 178/2002 Parlamentu Europejskiego $i$ Rady z dnia 28 stycznia 2002 r. ustanawiającym ogólne zasady i wymagania prawa żywnościowego, powołujacym Europejski Urzad ds. Bezpieczeństwa Żywności oraz ustanawiającym procedury w zakresie bezpieczeństwa żywności [...], w szczególności ze względu na zbliżajacy się upływ terminu przydatności do spożycia lub daty minimalnej trwałości lub ze względu na wady wyglądu tych środków spożywczych albo ich opakowań i przeznaczanie ich do unieszkodliwiania jako odpady". To właśnie wycofywana żywność i jej nieodpłatne przekazanie kościelnej osobie prawnej uznanej za organizację pozarządową z przeznaczeniem na wykonywanie przez tę organizację zadań w zakresie określonym w art. 2 pkt 2 u.p.m.ż. jest głównym przedmiotem umowy tych podmiotów ${ }^{18}$. Można wręcz stwierdzić, że na tym polega istota tego stosunku prawnego. Wykluczone jest odpłatne przekazy-

\footnotetext{
${ }^{17}$ Por. także S. WŁody KA, Ogólna charakterystyka umów handlowych, w: Prawo umów handlowych, red. S. Włodyka, System prawa handlowego, t. 5, Warszawa 2011, s. 23-24.

${ }^{18}$ Por. art. 3 ust. 1 u.p.m.ż.
} 
wanie żywności w ramach przedmiotowej ustawy. Jednakże nie każda wycofywana żywność podlega takiemu przekazywaniu. Wyłączeniu podlegają napoje alkoholowe o zawartości alkoholu powyżej 1,2\% oraz napoje alkoholowe będące mieszaniną piwa i napojów bezalkoholowych, w których zawartość alkoholu przekracza 0,5\% ${ }^{19}$. Niewątpliwie wyłączenie to nie ma charakteru ograniczającego w stosunku do sfery zadań publicznych czy też kościelnej działalności miłosierdzia i należy je zaaprobować.

Ustawodawca przewidział również konieczność zawarcia innych postanowień umownych (ius cogens). Po pierwsze strony powinny ustalić czas i sposób przekazywania żywności oraz jej rodzaj na wykonywanie przez kościelną osobę prawną zadań w zakresie określonym $\mathrm{w}$ art. 2 pkt $2^{20}$. Najczęściej te kwestie mają charakter techniczny i są rozbudowane, toteż można je uregulować w załącznikach do umowy stanowiących jej integralną część (np. harmonogram dostaw wraz z wzorem pokwitowania odbioru żywności).

Po drugie należy wprowadzić postanowienia umowne dotyczące podziału kosztów odbioru i dystrybucji żywności pomiędzy stronami umowy ${ }^{21}$. Wydaje się, że określenie „podziat” oznacza wprowadzenie odpowiedniej proporcji a nie obciążenia tymi kosztami tylko jednej strony umowy.

Po trzecie umowa powinna określać przypadki, w których kościelna osoba prawna może zrezygnować lub odmówić odbioru żywności ${ }^{22}$. Rezygnacja ma charakter definitywny, zaś odmowa może dotyczyć np. danej partii przekazywanej żywności.

Ostatni wymóg przewidziany w przedmiotowej ustawie dotyczy określenia okresu obowiązywania umowy oraz odpowiedzialności stron za niedotrzymanie warunków umowy, w tym warunków

\footnotetext{
${ }^{19}$ Por. tamże.

${ }^{20}$ Por. art. 3 ust. 2 pkt 1) u.p.m.ż. Jak wskazano w uzasadnieniu projektu ustawy: „W ust. 2 art. 3 projektu ustawy zawarto katalog elementów koniecznych, które powinna zawierać umowa dotycząca nieodpłatnego przekazywania żywności na cele społeczne”. Por. druk sejmowy nr 2431, s. 5.

${ }^{21}$ Por. art. 3 ust. 2 pkt 2) u.p.m.ż.

${ }^{22}$ Por. tamże, art. 3 ust. 2 pkt 3 ).
} 
wypowiedzenia ${ }^{23}$. Można zatem zawierać umowy na czas określony lub nieokreślony, każdorazowo pamiętając o odpowiednim okresie wypowiedzenia umowy a nawet wprowadzając przesłanki do odstąpienia od umowy (np. celowe wprowadzenia w błąd organizacji pożytku publicznego itp.). Kwestia odpowiedzialności stron w kontekście kościelnych osób prawnych nie powinna naruszać prawa kanonicznego w zakresie alienacji, co może mieć miejsce w przypadku nadmiernego zabezpieczenia umowy przez sprzedawcę żywności i wprowadzenie np. nadmiernych kar umowy. Z perspektywy kościelnych osób prawnych nie powinny się one zgadzać na tego typu kary, chyba że mają one charakter „symboliczny” i wyłączono by jednocześnie odpowiedzialność na zasadach ogólnych.

W tym miejscu należy wskazać, że przedmiotowe umowy są zawierane w ramach swobody umów, o której mowa w art. 3531 ustawy z dnia 23 kwietnia 1964 r. Kodeks cywilny ${ }^{24}$. Umowa może zatem zawierać inne postanowienia umowne, zarówno te wynikające z przedmiotowej ustawy jak i innych przepisów. Przykładowo w pierwszej kategorii w umowie można uregulować również kwestię współdziałania stron w ramach kampanii edukacyjno-informacyjnych w zakresie racjonalnego gospodarowania żywnością. Kościelna osoba prawna powinna zadbać o to, aby taka kampania nie naruszała jej dobrego imienia ${ }^{25}$. Przedmiotowe współdziałanie można również określić w odrębnej umowie. Można również dla przejrzystości powtórzyć zapisy ustawowe np. dotyczące wysokości kosztów administracyjnych kościelnych osób prawnych, które nie mogą przekraczać $20 \%$ opłaty wnoszonej przez sprzedawcę żywności ${ }^{26}$ czy też obowiązku przekazywania przez kościelne osoby prawne informacji o wykorzystaniu środków pochodzących $\mathrm{z}$ opłaty ${ }^{27}$. $\mathrm{Z}$ drugiej strony w umowie można dodawać różnego rodzaju typowe postanowienia umowne, jak chociażby odpowiednio dotyczące zabezpieczenia wykonania umowy czy

\footnotetext{
${ }^{23}$ Por. tamże, art. 3 ust. 2 pkt 4 ).

${ }^{24}$ Tekst jedn. Dz. U. 2019 poz. 1145 z późn. zm. Ustawa zwana dalej również k.c.

${ }^{25}$ Por. art. 4 ust. 1-2 u.p.m.̇.

${ }^{26}$ Por. tamże, art. 6 ust. 2, który wchodzi w życie z dniem 1 marca 2020 r.

${ }^{27}$ Por. tamże, art. 7 ust. 1, który wchodzi w życie z dniem 1 marca 2020 r.
} 
też postanowienia dotyczące ochrony danych osobowych, poufności, wykorzystywania wizerunku, podwykonawców, zbywania roszczeń, mierników staranności itp. Kościelne osoby prawne powinny również zadbać o to aby sprzedawca żywności nie mógł naruszać jej dobrego imienia jak również o przejrzysty zapis, że w sprawach nieuregulowanych w przedmiotowej umowie odpowiednie zastosowanie mają przepisy prawa kanonicznego.

\section{Zakończenie}

Na podstawie powyższej analizy można $\mathrm{z}$ aprobatą ocenić ustawę o przeciwdziałaniu marnowania żywności. Niewątpliwie wypełnia ona dotychczasową lukę i stanowi pierwszy krok w kierunku ochrony uprzednich wartości jakim w społeczeństwie polskim jest niewątpliwie szacunek do żywności. Należy zauważyć, że zagadnienie przeciwdziałania marnowania żywności nie było dotychczas przedmiotem szerszego orzecznictwa sądowego co powinno się zmienić wobec obowiązywania ustawy i jej realizacji przez organizacje pozarządowe, w tym kościelne osoby prawne oraz sprzedawców żywności. Wobec dotychczasowego braku orzecznictwa warto przyjmować proste postanowienia umowne i dbać o równość stron umowy uwzględniając różnice między nimi zachodzące.

Ponadto ustawa jest niezbyt rozbudowana i poprzez to odpowiednio przejrzysta. Stanowi ona również pośrednio element realizacji konstytucyjnej i konkordatowej zasady współdziałania Kościoła i państwa na rzecz dobra człowieka i dobra wspólnego.

Jednocześnie w ustawie uwzględniono dotychczasową (jak wskazano w uzasadnieniu projektu wielowiekową) działalność kościelnych osób prawnych w zakresie udzielania pomocy osobom ubogim poprzez przekazywanie im żywności i w ramach definicji organizacji pozarządowych zawarto również kościelne osoby prawne prowadzące odpowiednie zadania ze sfery zadań publicznych.

De lege ferenda należy przedstawić postulat odpowiedniej zmiany przepisów ustawy o podatku od towarów i usług i umożliwienie sprzedawcom żywności odliczenia podatku niezależnie od tego, czy współdziałają oni w ramach wykonywanych umów z podmiotami 
posiadającymi status organizacji pożytku publicznego lub nie posiadającymi takiego statusu.

\section{Church legal entities as NGOs involved in contractual cooperation under the Food Waste Act}

In the article was presented the issue of church legal entities, which are NGOs that participate in cooperation under the Act on combating food waste.

In the first part of the article was presented the form of the contract indicated in this Act, bearing in mind the additional requirements provided for in canon law. In the next part was presented the entities of this cooperation, in particular the legal definition of a non-governmental organization, which also includes church legal entities. The last part of the article concerns the subject of the contract. Contractual elements were divided into obligatory and optional elements and were described accordingly.

Important conclusions were presented in the end, including de lege ferenda conclusions.

SŁOWA KLUCZOWE: marnowanie żywności; organizacje pozarządowe; kościelne osoby prawne; działalność charytatywna; pomoc ubogim

KEYWORDS: food waste; non-governmental organizations; church legal person; charity; help the poor person

Nota o Autorze:

DR Micha£ Poniatowski - adiunkt w Katedrze Prawa Polskiego i Międzynarodowego Wydziału Prawa Kanonicznego UKSW. 